\title{
Relationship of Gadget Use With Sleep Quality in Pandemy Covid-19 In School Age Children in State Elementary School Goa Jereweh District West Sumbawa
}

\author{
Eka Adithia Pratiwi*, Lestari Ananda, Baik Heni Rispawati, Rias Pratiwi Safitri \\ STIKES YARSI Mataram, Indonesia \\ *pratiwiekaadithia@gmail.com
}

\begin{abstract}
Around 1.5 billion children have been dismissed from school due to the outbreak of Covid19 , as a result of which many of them are spending more time using electronic devices during the lockdown. According to data from the American Children's Academy, 75\% of 9-10 year olds experience sleep deprivation due to unsupervised use of technology. The purpose of this study was to determine the relationship between gadget use and sleep quality in school age children at Jereweh Goa state elementary school, Regency West Sumbawa. This study used a correlation design with a cross sectional approach. The data collection tool used a questionnaire. Data analysis used the Spearman-rho test. The results of this study found that there was no relationship between the use of gadgets and the quality of sleep during the Covid-19 pandemic in school-age children Goa Jereweh at state elementary school in 2020 with a P-Value of 0.653> 0.05 (insignificant). Recommend that parents can increase their activities and activities with children, such as involving children in home activities and exercising together to distract children from gadgets.
\end{abstract}

Keywords: School age children, Sleep Quality, Use of Gadgets 


\section{STRADA Jurnal Ilmiah Kesehatan}

DOI: $10.30994 /$ sjik.v9i2.497

ISSN: 2252-3847 (print); 2614-350X (online)

Vol.9 No.2 November 2020 Page.1680-1686

\section{BACKGROUND}

The Covid-19 pandemic is an event that the 2019 coronavirus disease has spread throughout the world. This disease is caused by a new type of coronavirus called SARSCoV-2. The Covid-19 outbreak was first detected in Wuhan City, Hubei Province, China in December 2019, and was declared a pandemic by the World Health Organization (WHO) on March 11, 2020 (id.wikipedia.org). Since April 2020, approximately 1.5 billion children have been dismissed from school and as a result many of them are spending more time using electronic devices to complete school assignments as part of learning from home, communicating with peers, or playing video games remembering activities. restricted outdoors due to lockdown. (www.emro.who.int).

Continuous use of gadgets will have a bad impact on children's behavior patterns in their daily lives, children who tend to use gadgets constantly will be very dependent and become activities that children should and routinely do in their daily activities. playing gadgets more often than learning and interacting with the surrounding environment (Moh. Saifullah, 2017). School-age children are children aged 6-12 years who have been able to react to intellectual stimuli or carry out learning tasks that require intellectual or cognitive abilities (Yusuf, 2011). The characteristics of school age children are generally like to play, like to move, like to work in groups, and like to practice directly (Abdul Alim in Erick Burhaen, 2017). School-aged children need nutritious food intake, exercise, a healthy environment, and adequate rest (Metta, 2013).

The American Academy of Pediatricians and the Canadian Children's Society emphasize that children aged 0-2 should not be exposed to technology at all. Children aged 3-5 years are limited to using technology one hour per day, children aged 6-18 years are limited to 2 hours per day. Children can experience sleep deprivation and lack of focus which leads to unhealthy sleep cycles as children are more sleepy during the day and sleep less at night. If every 15 minutes a child uses a gadget it means they lose 60 minutes of sleep time. According to data from the American Academy of Children, 75\% of children aged 9-10 years experience sleep deprivation due to unsupervised technology use. (The Asian Parent Insight, 2018).

The use of gadgets is prohibited in early childhood under 12 years of age due to negative impacts on children such as brain growth that is too fast due to stimulation from gadgets, barriers to child development that have an impact on language skills and achievement at school, risk of obesity, sleep disorders, disease mental, aggressive, digital senility, addiction or dependence, radiation, education from gadgets will not last long in children's memories (Muhimmatul Hasanah, 2017). Another effect caused by the use of electronic media on sleep is the continuous stimulation of the brain, so that people who use it find it difficult to relax and tend to stay awake (National Sleep Foundation, 2014).

The NSF (National Sleep Foundation) released the Annual Sleep in America Poll in 2011 to look at the effects of using electronic media before bedtime. The survey results showed $95 \%$ of the total respondents, aged 13-64 years, use electronic media before going to bed and 43\% of them complain that they rarely or never get satisfying sleep. Even 7\% of respondents aged 13-18 years admit that they sleep less than 6 hours at night (Saifullah, 2017).

Sleep is very important for the biopsy chosocial development of children. Children who have difficulty sleeping experience lack of sleep time so that the child becomes hyperactive and acts excessively near bedtime. Signs of a child experiencing lack of sleep include frequent drowsiness, difficulty waking up in the morning, and irritability and irritability during the day (Moh. Saifullah, 2017). The causes of reduced quality of sleep in children, namely the use of electronic media are often associated with reduced sleep 


\section{STRADA Jurnal Ilmiah Kesehatan}

DOI: $10.30994 /$ sjik.v9i2.497

ISSN: 2252-3847 (print); 2614-350X (online)

Vol.9 No.2 November 2020 Page.1680-1686

duration, waking up early, sleepiness during the day, nightmares at night, and sleepwalking (Arora et al., 2014).

Based on a preliminary study conducted at SDN Goa Jereweh, the number of students who have personal cell phones is as many as 36 students, while 71 students use their parents' cellphones, using them to communicate with friends and to play games. There are 10 students who have tablets at home, while 28 students have laptops at home. Based on the results of the interview, it was found that children in Goa Village during the Pandemic used gadgets as a medium for learning. But apart from that, children use gadgets for entertainment such as playing games, watching videos without parental control which results in the child's learning quality being not optimal. In addition, it was found that children had a lack of sleep where the children slept after 10 at night and had to wake up at 5 or 6 in the morning.

\section{METHODS}

This study used a correlation design with a cross sectional approach. This research was conducted on September 7 - 9 2020. The variables in this study were the use of gadgets and sleep quality. The population of students in grades 1-6 at Jereweh Goa state elementary school with a total sample of 100 respondents. The sampling method used in this research is Proportional Stratified Random Sampling. The data used in this study are primary data, namely the use of gadgets using a questionnaire from The American Academy of Pediatrics (AAP), while the quality of children's sleep uses the Pittsburgh Sleep Quality Index (PSQI) questionnaire.

Univariate data analysis was carried out on each variable from the research results by looking for the distribution and percentage of research results so that they could describe the respondents in this study. Meanwhile, bivariate data analysis was conducted to determine the relationship or correlation between two variables, namely the use of gadgets and sleep quality. The bivariate data analysis used was Spearman-rho.

\section{RESULTS}

Characteristics of respondents based on age.

Table 1. Distribution of respondents by age.

\begin{tabular}{cccc}
\hline No. & Age (Year) & $\mathrm{N}$ & $\%$ \\
\hline 1. & 6 & 1 & 1 \\
2. & 7 & 18 & 18 \\
3. & 8 & 16 & 16 \\
4. & 9 & 15 & 15 \\
5. & 10 & 26 & 26 \\
6. & 11 & 17 & 17 \\
7. & 12 & 7 & 7 \\
\hline
\end{tabular}

Source: Primary Data 2020

Table 1 above shows that the largest number of respondents were in the 10 year age group, namely 26 respondents $(26 \%)$. 


\section{STRADA Jurnal Ilmiah Kesehatan}

DOI: $10.30994 /$ sjik.v9i2.497

ISSN: 2252-3847 (print); 2614-350X (online)

Vol.9 No.2 November 2020 Page.1680-1686

Characteristics of respondents based on gender

Table 2. Distribution of respondents based on gender.

\begin{tabular}{cccc}
\hline No. & Gender & N & $\%$ \\
\hline 1 & Man & 47 & 47 \\
2 & Woman & 53 & 53 \\
\hline & Total & 100 & 100 \\
\hline
\end{tabular}

Source: Primary Data 2020

Table 2 above shows that most of them are female, namely 53 respondents (53\%).

Characteristics of respondents based on the type and need for using the gadget they have

Table 3. Frequency distribution of types of gadgets owned by Goa Jereweh primary school students

\begin{tabular}{clcc}
\hline No. & \multicolumn{1}{c}{ Gadget } & $\mathrm{N}$ & $\%$ \\
\hline 1. & Kind of Gadget Handphone & 99 & $99 \%$ \\
2 & Tablet $\quad$ Total & 1 & $1 \%$ \\
\hline \multicolumn{4}{c}{ The need for using gadgets } \\
1 & Searching for information & 100 & $100 \%$ \\
2 & Playing social media & 64 & 64 \\
3 & Watching video & 9 & 9 \\
4 & Playing games & 17 & 17 \\
\hline & $\quad$ Total & 100 & 100 \\
\hline
\end{tabular}

Source: Primary Data 2020

Table 3 above shows that the most types of gadgets owned are Mobile as many as 99 respondents (99\%) with 64 respondents (64\%) using gadgets to find information.

Table 4. Overview of the use of gadgets

\begin{tabular}{clccc}
\hline No. & & Use of Gadget & $\mathrm{N}$ & $\%$ \\
\hline 1. & Low & & 25 & $25 \%$ \\
2. & Modrate & & 66 & $66 \%$ \\
3 & High & & 9 & $9 \%$ \\
\hline \multicolumn{2}{r}{} & Total & 100 & $100 \%$ \\
\hline
\end{tabular}

Source: Primary Data 2020

Table 4 above shows that the most gadget usage is in the medium category as many as 66 respondents $(66 \%)$. 
STRADA Jurnal Ilmiah Kesehatan

DOI: $10.30994 /$ sjik.v9i2.497

ISSN: 2252-3847 (print); 2614-350X (online)

Vol.9 No.2 November 2020 Page.1680-1686

\begin{tabular}{ccccc}
\hline No. & & Sleep Quality & N & $\%$ \\
\hline 1. & Good & & 96 & 96 \\
2. & Bad & & 4 & 4 \\
\hline & & Total & 100 & 100 \\
\hline
\end{tabular}

Table 5. Overview of sleep quality

Source: Primary Data 2020

Table 5 above shows that most of the sleep quality was in the good category as many as 96 respondents $(96 \%)$.

Table 6.The relationship between gadget use and sleep quality during the Covid pandemic 19

\begin{tabular}{|rl|r|r|}
\hline & & Use of Gadget & \multicolumn{1}{|c|}{ sleep quality } \\
\hline Spearman's rho Use of & Correlation & 1,000 &,- 046 \\
Gadget & Coefficient & &, 653 \\
& Sig. (2-tailed) & 100 & 100 \\
& $\mathrm{~N}$ &,- 046 & 1,000 \\
\cline { 2 - 4 } & Correlation & & \\
Sleep & Coefficient &, 653 & 100 \\
\hline
\end{tabular}

Table 6 above shows that the Spearman's rho $r$ value is -0.046 with Sig. (2-tailed) 0.653 greater than $\alpha=0.05$, which means that there is no relationship between the use of gadgets and the quality of children's sleep during the Covid-19 pandemic in school-age children at Jereweh Goa State Elementary School.

\section{DISCUSSION}

\section{Use of Gadgets}

The results showed the use of gadgets during the Covid-19 pandemic as many as 25 respondents $(25 \%)$ were included in the low category of gadget users, 66 respondents $(66 \%)$ were included in the medium category of gadget users, and 9 respondents $(9 \%)$ were included in the category gadget users. high. The results of research on the use of gadgets in GOA Jereweh State Elementary School, West Sumbawa in 2020, it was found that the most types of gadgets they owned and the most widely used were the types of mobile phones, which were 99 students (99\%).

Mobile is an innovation of the latest technology with better capabilities and the latest features that have a more practical and also more useful purpose and function. According to Kumiko Aoki and Edward J. Downes (2003), there are 9 reasons that encourage someone to use a cellphone, namely security where cellphones are seen as providing psychological security if someone is on a trip or away from family, cellphones are used because they are cheap and practical, the need for access to information encourages people, especially young people to use cellphones, supports social interaction, communicates with families, reasons for time management and coordination, maintains privacy, supports self-existence, and is addicted to mobile phones (Hendra Wardhana, 2013).

On average students use gadgets for information seeking purposes with a frequency of 64 students $(64 \%)$, then watch videos as many as 17 children (17\%), play games as many as 11 children $(11 \%)$, and the least for the needs of playing social media 


\section{STRADA Jurnal Ilmiah Kesehatan}

DOI: $10.30994 /$ sjik.v9i2.497

ISSN: 2252-3847 (print); 2614-350X (online)

Vol.9 No.2 November 2020 Page.1680-1686

is 9 children (9\%). Based on observations made at GOA Jereweh State Elementary School, West Sumbawa, it was found that some children used gadgets for learning and looking for subject matter. This can be caused by the ongoing pandemic situation which requires children to do learning from home in the context of distance learning (PJJ).

If gadgets are used for educational purposes, it will have a positive impact on children, namely, they can increase knowledge, expand friendship networks, facilitate communication, and train children's creativity. The Asian Parent Insight with Samsung Kidstime through Mobile Device Usage Among Young Kids conducted a survey of 500 parents in Indonesia which resulted in several findings, namely, 80\% of parents allowing their children to use smartphones for educational purposes. In fact, $72 \%$ of children use smartphones / tablets for playing games, $57 \%$ for educational applications, and $14 \%$ for book applications.

This is in line with research conducted by Muhammad Zaini and Soenarto (2019) regarding Parents' Perceptions of the Presence of the Digital Technology Era in Early Childhood, where it was found that $50 \%$ of children play smartphones and tablets for the benefit of education and games, $28 \%$ of children play. smartphones and tablets for educational purposes, $22 \%$ of children play smartphones and tablets to play games. The percentage of smartphone and tablet usage for educational purposes is somewhat higher than games.

\section{Sleep Quality}

The results of the study using the PSQI (Pittshburgh Sleep Quality Index) questionnaire found that 96 students (96\%) had good sleep quality and 4 students (4\%) had poor sleep quality. School-age children sleep between 8-12 hours a night without naps. 8 year olds need at least 10 hours of sleep per night. In children aged 11 to 12 years they often sleep at 10 at night. REM sleep in children this age is reduced by about $20 \%$. Although some children still experience waking up at night and nightmares, this problem will get better by itself with age (Moh. Saifullah, 2017).

This is in line with research conducted by Adi et al (2018), where it is said that children aged 9-12 years need sufficient sleep to improve their health and body condition to stay healthy. This research is proven by the results of research which states that as many as $57.4 \%$ of children in State Elementary School 1 Petungsewu, Dau District, Malang Regency, experience good sleep quality and $44 \%$ of children with good emotional intelligence. This is due to environmental support and good motivation.

From the demographic data based on gender, it can be seen that the highest value of sleep quality variables is in female respondents as many as 53 people (53\%). This is due to the habits of men and women living in the night. Overall tolerance for late night activity in men will cause sleep management to be different from sleep management for women. One of the observations states that boys can tolerate late night playtime, whereas girls are more regular in managing sleep time (Fuad, et al, 2005).

\section{CONCLUSION}

Based on the results of bivariate data analysis research, it was found that the p-value was $0.653>0.05$, so it was said to be insignificant. Therefore, it can be concluded that there is no relationship between gadget use and sleep quality during the Covid-19 pandemic in school-age children at Jereweh Gowa State Elementary School regency West Sumbawa in 2020. The use of gadgets by students at Jereweh Gowa State Elementary School during the Covid-19 Pandemic is in the moderate category as much as 66\%. Likewise with the quality 


\section{STRADA Jurnal Ilmiah Kesehatan}

DOI: $10.30994 /$ sjik.v9i2.497

ISSN: 2252-3847 (print); 2614-350X (online)

Vol.9 No.2 November 2020 Page.1680-1686

of sleep in school-age children in Jereweh Gowa State Elementary School students during the Covid-19 Pandemic, which is as many as $96 \%$ of students get good quality sleep.

\section{REFERENCES}

Indonesian Internet Service Providers Association. 2015. Indonesian Internet User Profile 2014. Jakarta: Indonesian Internet Service Providers Association.

Burhaen, Erick. 2017. Physical Activity of Sports for Growth and Development of Elementary School Students. Accessed from https://ejournal.upi.edu/index.php/IJPE/article/view/7497 on 13 September 2019, $12: 15$.

Carter, Ben, et al. 2016. Association Screen-Based Media Device Access or Use and Sleep Outcomes. Accessed from http://jamanetwork.com/journals/jamapediatrics/fullarticle/2571467 on September $16,2019,09: 16$

Emro.who.int. Consideration For Young People on Excessive Screen Use During Covid-19. Accessed from http://www.emro.who.int/mnh/news/considerations-for-youngpeople-on-excessive-screen-use-during-covid19.html on 14 August 2020, at 01:22

Hasanah, Muhimmatul. 2017. The Effect of Gadgets on Children's Mental Health. Accessed from http://garuda.ristekbrin.go.id/documents/detail/722753 on September 13, 2019, $14: 18$

Id.m.wikipedia.org. The Covid-19 pandemic. April 4, 2020. Accessed from http://id.m.wikipedia.org/wiki/Pandemi_COVID-19 on August 7, 2020, at 13:00.

Kozier. (2010). Clinical Nursing Practice Textbook. Edition 5. Jakarta: EGC

Tanjung, MF Conny and Rini Sekartini. 2004. Sleep Problems in Children. Jakarta. Sari Pediatrics.

Widiawati \& Sugiman. 2014. The effect of the use of gadgets on children's developmental power. Accessed from http://stmikglobal.ac.id/wpcontent/uploads/2014/05/ARTIKELIIS.pdf on January 14, 2020, 17:08

Saifullah, Moh. 2017. The Relationship between Gadget Use and Sleep Patterns in School Children at UPT SDN Gadingrejo II Pasuruan. IR-Library of Airlangga University. Surabaya. (Essay)

Sun, Erick. 2014. Melatonin and Sleep. Accessed from http://www.sleepfoundation.org/articles/melatonin-and-sleep on September 13, 2019. $5: 50 \mathrm{pm}$

Yusuf, H. Syamsu. 2011. Developmental Psychology of Children \& Adolescents. Bandung. Rosdakarya youth. 